\title{
GLOBAL PLANT HARDINESS ZONES FOR PHYTOSANITARY RISK ANALYSIS
}

\author{
Roger D. Magarey ${ }^{1,2 *}$; Daniel M. Borchert ${ }^{2}$; Jay W. Schlegel ${ }^{3}$

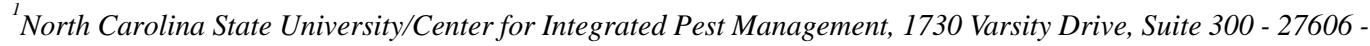 \\ Raleigh, NC. \\ ${ }^{2}$ USDA/Center for Plant Health Science and Technology, Plant Epidemiology and Risk Analysis Laboratory, \\ Plant Protection and Quarantine, Animal Plant Health Inspection Service - 27606 - Raleigh, NC. \\ ${ }^{3}$ ZedX Inc., 369 Rolling Ridge Drive - 16823 - Bellefonte, PA. \\ *Corresponding author <Roger.D.Magarey@aphis.usda.gov>
}

\begin{abstract}
Plant hardiness zones are widely used for selection of perennial plants and for phytosanitary risk analysis. The most widely used definition of plant hardiness zones (United States Department of Agriculture National Arboretum) is based on average annual extreme minimum temperature. There is a need for a global plant hardiness map to standardize the comparison of zones for phytosanitary risk analysis. Two data sets were used to create global hardiness zones: i) Climate Research Unit (CRU) 1973-2002 monthly data set; and ii) the Daily Global Historical Climatology Network (GHCN). The CRU monthly data set was downscaled to five-minute resolution and a cubic spline was used to convert the monthly values into daily values. The GHCN data were subjected to a number of quality control measures prior to analysis. Least squares regression relationships were developed using GHCN and derived lowest average daily minimum temperature data and average annual extreme minimum temperatures. Error estimate statistics were calculated from the numerical difference between the estimated value for the grid and the station. The mean absolute error for annual extreme minimum temperature was $1.9^{\circ} \mathrm{C}$ $\left(3.5^{\circ} \mathrm{F}\right)$ and $2 / 3$ of the stations were classified into the correct zone.
\end{abstract}

Keywords: climate, plant diseases, minimum temperature

\section{ZONAS GLOBAIS DE RESISTÊNCIA ÀS PLANTAS PARA ANÁLISE DE RISCO FITOSSANITÁRIO}

\begin{abstract}
RESUMO: Zonas de resistência às plantas, definidas pelo "United States Department of Agriculture National Arboretum" com base na média anual das temperaturas mínimas extremas, são amplamente utilizadas para a seleção de plantas perenes e para a análise de risco fitossanitário. Há necessidade de um mapa global para padronizar a comparação de zonas nas análises de risco fitossanitário. Dois bancos de dados climatológicos foram utilizados para criar tais zonas globais de resistência às plantas: i) conjunto de dados mensais de 1973-2002 da "Climate Research Unit (CRU)"; e ii) dados climatológicos diários da "Daily Global Historical Climatology Network (GHCN)". Os dados mensais da CRU foram ajustados a uma escala reduzida de resolução de cinco minutos, e um ajuste cúbico foi empregado para converter os dados mensais para diários. Os dados da RDGH foram submetidos a várias medidas de controle de qualidade antes de serem empregados nas análises. Relações de regressão pelo método dos mínimos quadrados foram desenvolvidas usando dados da RDGH, resultando nos mais baixos valores médios diários de temperatura mínima e média anual das temperaturas mínimas extremas. Os erros estatísticos estimados foram calculados a partir da diferença numérica entre os valores estimados para a malha e os observados nas estações climatológicas. $\mathrm{O}$ erro médio absoluto para a temperatura mínima extrema anual foi $1,9^{\circ} \mathrm{C}\left(3,5^{\circ} \mathrm{F}\right)$, o que possibilitou a classificação de $2 / 3$ das estações dentro das zonas corretas.

Palavras-chave: clima, doenças de plantas, temperatura mínima
\end{abstract}

\section{INTRODUCTION}

The growth and survival of most terrestrial plants is influenced by extreme low temperature (Woodward \& Williams, 1987). For example, the distribution of evergreen broadleaf vegetation has been shown to be correlated with $-15^{\circ} \mathrm{C}\left(5^{\circ} \mathrm{F}\right)$ (Woodward
\& Williams, 1987). A commonly used indicator of the influence of climate on plant growth and survival is the hardiness zone. The United States Department of Agriculture National Arboretum (USDA-NA) hardiness zones are based on the average annual extreme minimum temperature (Cathey, 1990) but other definitions of hardiness zones also exist. For example, the Cana- 
dian hardiness zones take into account the influence of seven variables including frost free days, average minimum temperature and precipitation of the coldest month (McKenney et al., 2001).

Hardiness zones were developed primarily for making planting recommendations for perennial plants (Cappiello \& Littlefield, 1994; Cathey, 1990; McKenney et al., 2006), but have also been used for phytosanitary risk analysis as an indicator of establishment potential (Evans et al., 2007; Jefferson et al., 2004; Venette \& Gould, 2006). As an indication of climatic suitability, the USDA Animal Plant Health Inspection Service (APHIS) uses plant hardiness zones for its commodity risk analyses (USDA, 2003). For example, under this 2003 version of the guidelines, a pest receives a high ranking for climate suitability if it occurs in four or more plant hardiness zones, but a low ranking if it occurs in a single plant hardiness zone.

One of the limitations of the current risk analysis procedure is the lack of a single global plant hardiness map. Currently risk analysts must consult multiple sources (plant, 2007), which may use different and often undefined methodologies and time periods, making comparisons with US hardiness zones difficult. In addition, climate change has created a need to update many of the older maps. The objective of this study was to create an updated, uniform global plant hardiness map which could be used as a phytosanitary risk analysis tool.

\section{MATERIAL AND METHODS}

Two sources of weather data were used to generate the plant hardiness zone maps, the Climate Research Unit (CRU) monthly data and the Daily Global Historical Climatology Network (GHCN) station data. The global CRU monthly average data set, which covers a period of more than 100 years, is a well known data set for climate change studies and is available from the Intergovernmental Panel of Climate Change (IPCC) website. The CRU data set used for this project consists of gridded monthly average minimum temperature data for the 1973-2002 period at a resolution of 0.5 degree latitude $\times 0.5$ degree (approximately $55 \mathrm{~km}$ depending on latitude) longitude. A major advantage of using the gridded CRU data set is that it contains values for all land areas of the world except Antarctica.

The CRU gridded monthly data were used to compute thirty-year monthly and daily averages. A proprietary version of an optimal interpolation technique (OI) (3-D interpolation) (Lorenc, 1981) was used to downscale the resolution from 0.5 degrees to 5 -minutes $(9.2 \mathrm{~km})$. This $3-\mathrm{D}$ interpolation technique takes into account the point elevation of the $9.2 \mathrm{~km}$ pixel. A cubic spline was employed to convert the monthly minimum temperature averages to daily values. These average minimum daily values were used to determine the lowest daily value that occurs during the year.

The GHCN station data contains daily values of maximum and minimum temperature and precipitation for more than 43,000 locations worldwide (Peterson \& Vose, 1997). The GHCN station data were used for extracting extreme minimum temperature information, but the density of this data were variable both temporally and spatially, especially outside North America and Europe. The variable nature of the GHCN station data makes the global scale assessments of plant hardiness difficult. To ensure stability in determining Plant Hardiness Zones (PHZ) on a global scale regardless of the variability of the GHCN data, relationships between daily CRU data and GHCN data were determined using one-dimensional regressions.

Before the GHCN data could be used in PHZ assessment, some quality control checks were performed on the data. These checks were done in addition to quality control checks performed by the National Climatic Data Center (Gleason, 2002), which produces the GHCN data set. The first check was to determine the degree of completeness for each station. Only those stations that reported at least $67 \%$ of the time (or at least 20 years during the 1978-2007 period were used in this study. There were over 6,500 stations worldwide that met this criterion (Figure 1). Highest station density is seen in North America while parts of Africa, India, Brazil and the Middle East have few, if any stations (Figure 1).

Each station was subjected to plausibility tests to determine if average annual extreme minimum temperatures for the thirty-year period and annual frequencies fell within plausible limits. Minimum temperatures were rejected if they fell outside the bounds of $-81.3^{\circ} \mathrm{C}$ $\left(-130^{\circ} \mathrm{F}\right)$ or $68.8^{\circ} \mathrm{C}\left(110^{\circ} \mathrm{F}\right)$. If the minimum temperature was equal to or greater than the maximum temperature for the day, it was rejected. To test if annual frequencies were in plausible limits, the characteristics of each station were compared to ten or more neighboring stations. To pass this quality control check, each candidate station had to have values within 3.0 standard deviations if the stations were located within 5 degrees of each other. If the ten stations were more than 5 degrees apart, the values were allowed to vary up to 3.5 standard deviations before rejection.

The GHCN data were used to create a set of six least squares regression relationships between the lowest average daily minimum temperature data and the average annual extreme minimum temperature. The 
following procedure was used to create the six regressions. First, global temperature regimes were classified into six zones (Table 1). The GHCN stations in each of those temperature ranges were used to calculate the regression equation for that zone. Next, the CRU climatology was used to determine the lowest average daily minimum temperature for each pixel. The appropriate regression equation based on the CRU derived lowest average daily minimum temperature was applied to estimate the average annual extreme minimum temperature. Finally, the estimated average annual extreme minimum temperature (Figure 2) was used to determine the hardiness classification for all land areas, except Antarctica.

Plant hardiness zones were estimated from annual average extreme minimum temperature using the USDA-NA zone definitions (Cathey, 1990). The
USDA-NA definition defines 11 zones from $-45.6^{\circ} \mathrm{C}$ $\left(-50^{\circ} \mathrm{F}\right)$ to above $4.4^{\circ} \mathrm{C}\left(40^{\circ} \mathrm{F}\right)$ in $6.25^{\circ} \mathrm{C}\left(10^{\circ} \mathrm{F}\right)$ increments. Many of the USDA-NA zones are subdivided into $a$ and $b$ based on $3.125^{\circ} \mathrm{C}\left(5^{\circ} \mathrm{F}\right)$ increments. Hardiness zones were using thirty-years (1978-2007) of GHCN data and by using USDA-NA methodology that was modified by adding zones 12 and 13. Zones 12 and 13 represent an extension of the USDA-NA zones in $10^{\circ} \mathrm{F}$ increments above $10^{\circ} \mathrm{C}\left(50^{\circ} \mathrm{F}\right)$ and $15.6^{\circ} \mathrm{C}$ $\left(60^{\circ} \mathrm{F}\right)$, respectively.

Error estimates were calculated by comparing the estimated average annual extreme minimum temperatures for each station with the observed GHCN station value. Regression equations for average annual extreme minimum temperatures were calculated without inclusion of the target station values. Using those equations, average annual extreme minimum tempera-

Table 1 - Global temperature regimes of average annual lowest minimum temperatures $\left(\mathrm{Tmin}^{\circ} \mathrm{C}\right)$ used to create the regression equations. Relationships for the six zones were found using the average annual lowest minimum temperatures and the average annual extreme minimum temperatures from the GHCN dataset.

\begin{tabular}{lccc}
\hline Zone & Temperature Range ${ }^{\circ} \mathrm{C}$ & Number of Input Stations in range & Regression \\
\hline 1 & $<-40$ & 10 & $0.650 \times(($ Tmin -32$) / 1.8)-35.230$ \\
2 & -40 to -28.9 & 87 & $0.678 \times(($ Tmin -32$) / 1.8)-30.287$ \\
3 & -28.9 to -17.8 & 687 & $0.830 \times(($ Tmin -32$) / 1.8)-27.789$ \\
4 & -17.8 to -6.7 & 2788 & $1.233 \times(($ Tmin -32$) / 1.8)-28.949$ \\
5 & -6.7 to 4.4 & 2480 & $1.493 \times(($ Tmin -32$) / 1.8)-33.636$ \\
6 & $>4.4$ & 587 & $1.254 X(($ Tmin -32$) / 1.8)-25.694$ \\
\hline
\end{tabular}

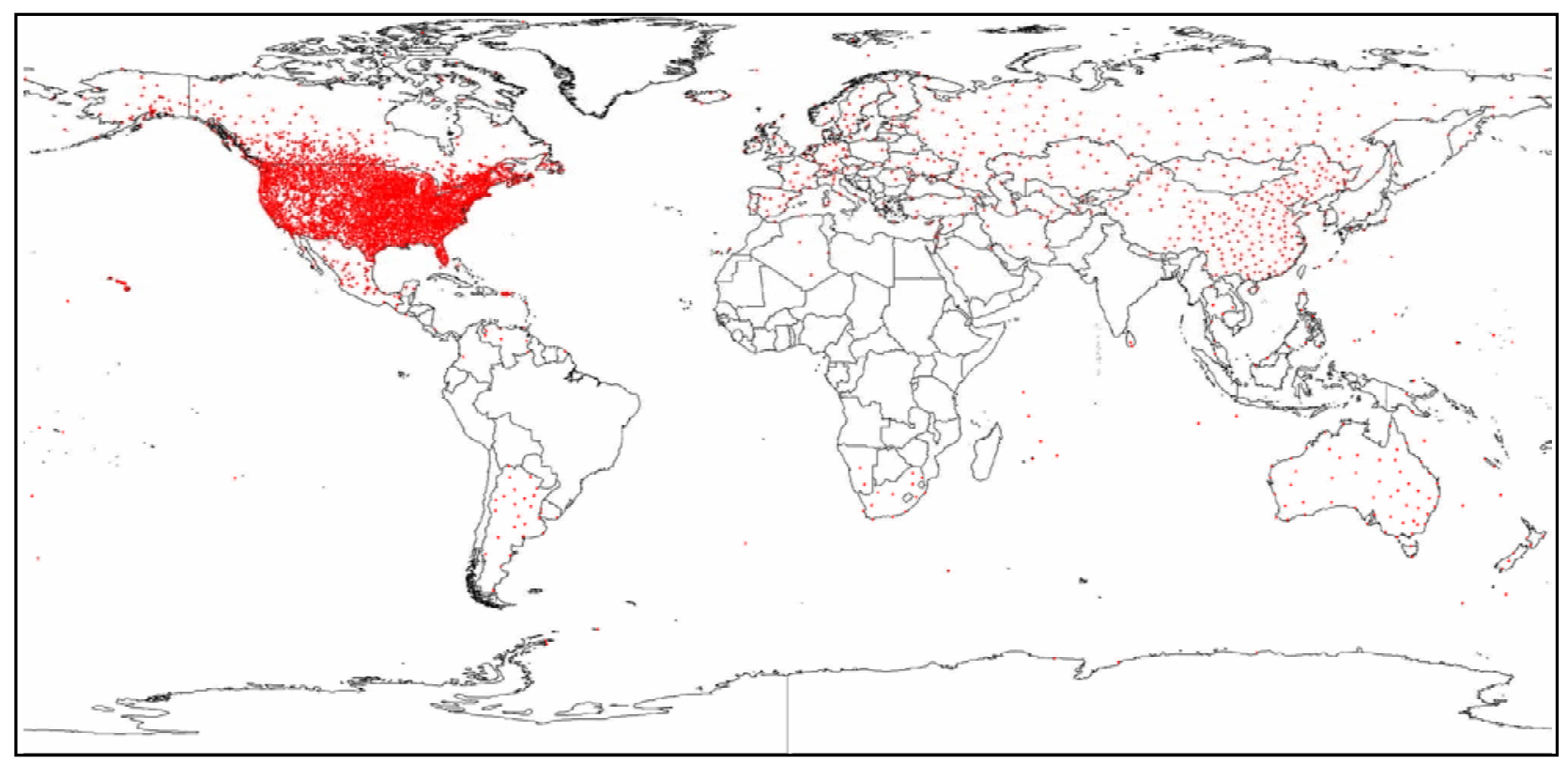

Figure 1 - Locations of Daily Global Historical Climatology Network (GHCN) stations reporting at least 67 percent of the time (at least 20 years for the 1978-2007).

Sci. Agric. (Piracicaba, Braz.), v.65, special issue, p.54-59, December 2008 
tures were calculated for the target stations. Statistics were then derived by comparing the estimated and observed GHCN station values. The calculated statistics included the mean, bias (mean error), mean absolute error (MAE), correlation coefficient (r-square) and the MAE for the $95^{\text {th }}$ percentile (Wilks, 1995). In addition, the numbers and percentages of GHCN stations for which the observed plant hardiness zone was lower, the same or higher than the estimated grid value was calculated without inclusion of the target station values.

\section{RESULTS}

The CRU and GHCN data sets provide researchers to ability to create PHZ maps with a more consistent methodology (Figure 3). Moreover, the PHZ maps can be updated annually with little effort. Visual comparisons with the current PHZ map with other PHZ maps across the globe using different data sets and temporal periods show similar patterns. One weakness of the methodology used to create the PHZ map is found over

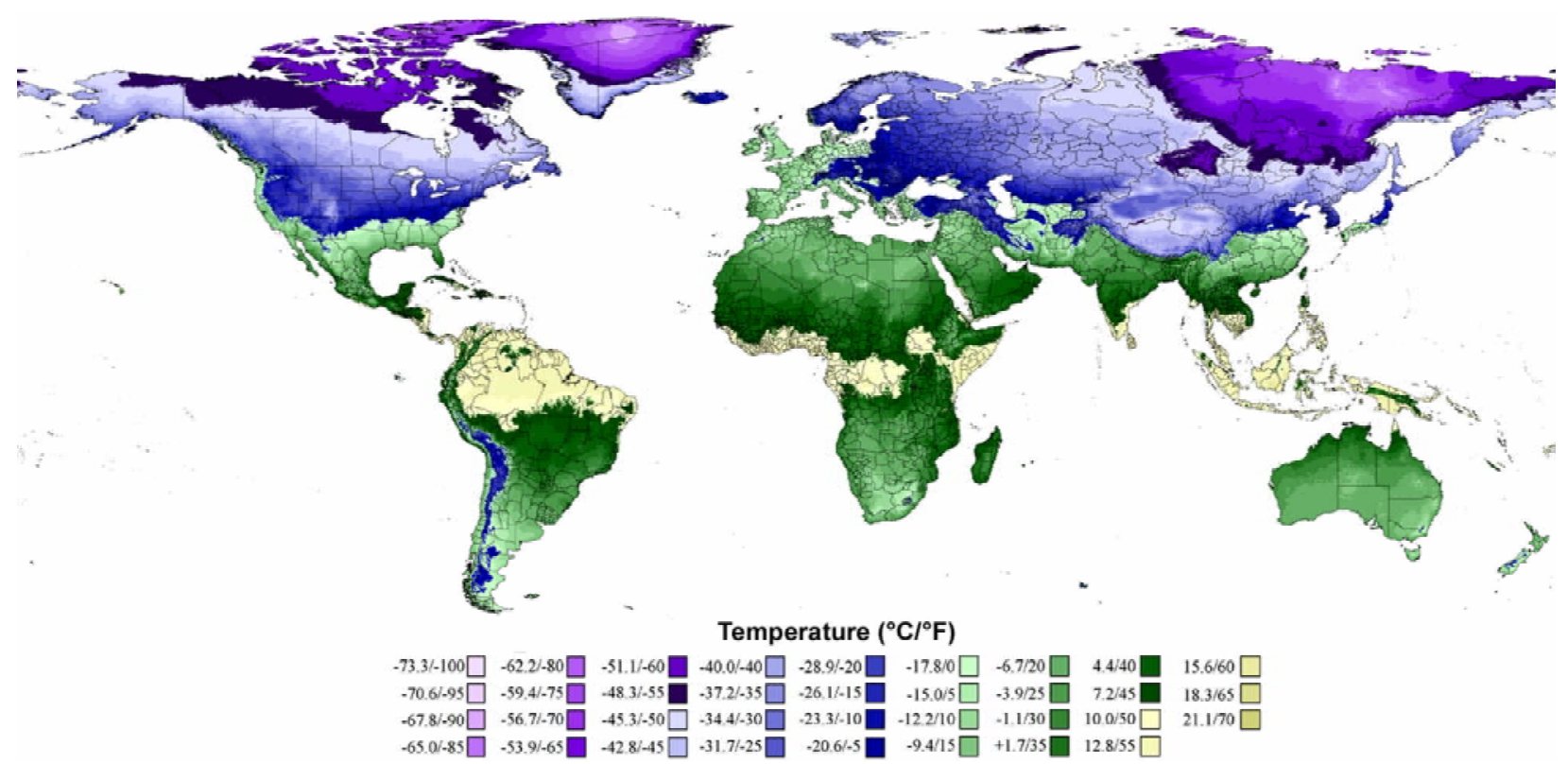

Figure 2 - Thirty-year average extreme minimum temperature for the period 1978-2007. Classes show upper temperature boundaries.

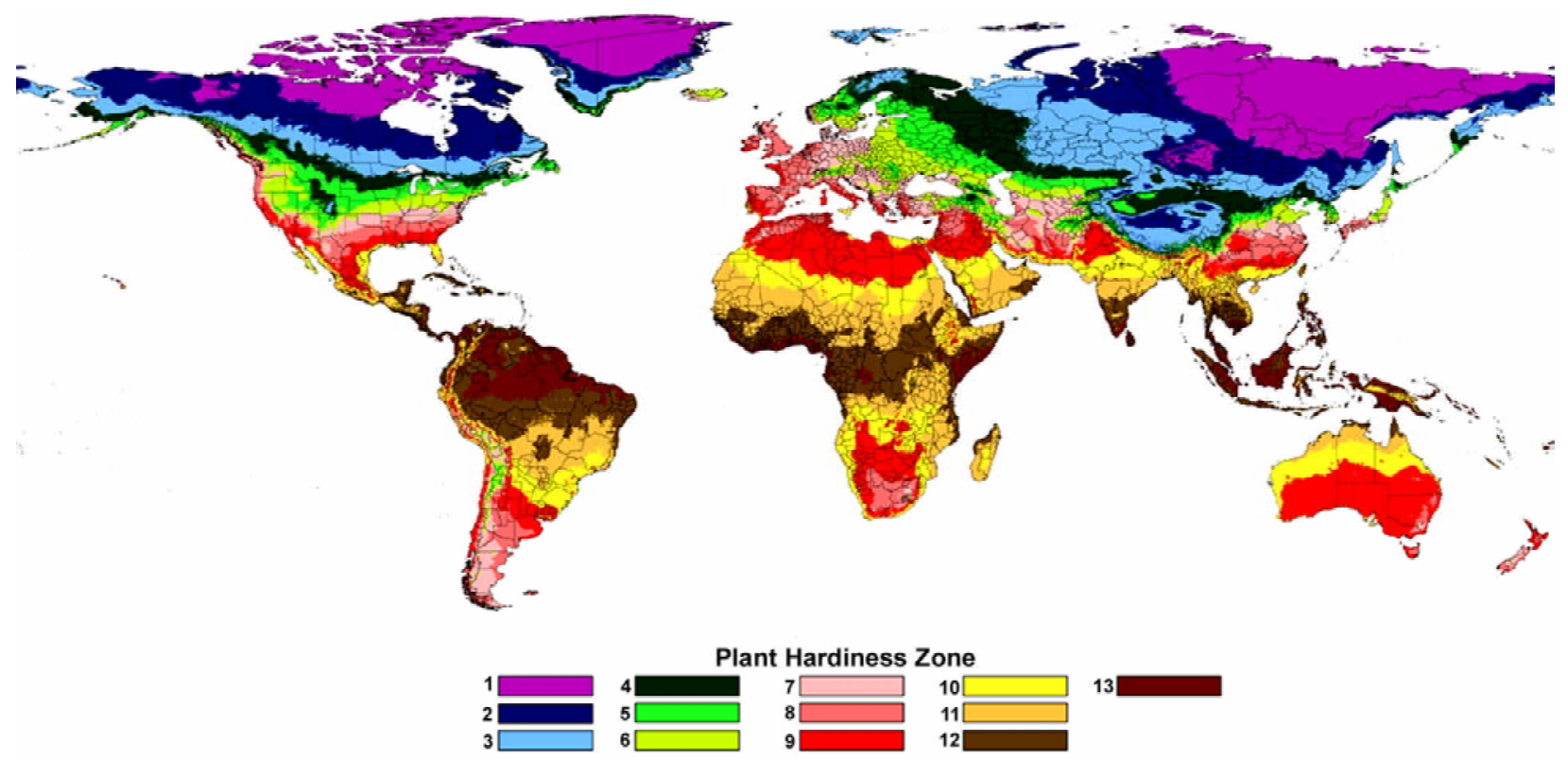

Figure 3 - Thirty-year global plant hardiness zone map for the period 1978-2007.

Sci. Agric. (Piracicaba, Braz.), v.65, special issue, p.54-59, December 2008 
Table 2 - Error estimates for average annual extreme minimum temperature $\left({ }^{\circ} \mathrm{C}\right)$.

\begin{tabular}{lcccccc}
\hline \# obs. & Grid mean & Station mean & Bias $^{1}$ & MAE $^{2}$ & MAE95\% $^{3}$ & R-squared $^{2}$ \\
\hline 6038 & -15.8 & -15.8 & 0.00 & 1.94 & 5.44 & 0.963 \\
\hline
\end{tabular}

${ }^{1}$ Bias - Mean error between grid and GHCN station values. ${ }^{2}$ MAE - Mean absolute error between grid and GHCN station values. Grid values were calculated without inclusion of the target station values. ${ }^{3}$ MAE95\% - Mean absolute error for the $95^{\text {th }}$ percentile.

small oceanic islands. PHZ zones may not be correctly classified in some of these areas because data are too limited for the modeling methods used in this study.

The method of using regression relationships to estimate average extreme annual temperature provided good results. The grid values of estimated temperature were compared with the observed station temperature. The mean absolute error between the estimated and observed station values was $1.94^{\circ} \mathrm{C}\left(3.5^{\circ} \mathrm{F}\right)$ for the thirty-year (1978-2007) period (Table 2). In addition, the PHZ classification based on the grid value was compared to that based on the station data. Approximately two-thirds of stations are classified into the correct PHZ (Table 3).

\section{DISCUSSION}

The global plant hardiness zone map will allow a phytosanitary analyst to easily compare plant hardiness zones without having to consult multiple maps which may have been created with different methodologies and time periods. Since the thirty-year map was created from the period from 1978 to 2007 data, it is more recent and uniform in methodology than some of the maps that have been used previously for risk analysis. For example, some plant hardiness maps show only a small area of PHZ zone 11 in southern Florida while the recent map indicated a larger portion of the state in that zone. This is an important change since Florida is susceptible to frequent exotic pest introductions (Frank \& McCoy, 1995), has the busy port and airport of Miami, and is a major producer of plants, fruits and vegetables.

Because of increased global mobility of pests and influence of climate change on species distribution, it is important for PHZ maps to be updated frequently on a global scale. The influence of climate change on species distribution has been well documented in recent years (Parmesan \& Yohe, 2003; Walther et al., 2002). Parmesan \& Yohe (2003) used meta-analysis techniques for 1,700 species to document significant range shifts averaging $6.1 \mathrm{~km}$ per decade towards the poles and significant mean advancement of spring events by 2.3 days per decade. When climate change is coupled with human interactions there is the potential for more dramatic changes in distribution, for example the spread of thermophilous plants from gardens into surrounding countryside (Walther et al., 2002).
Table 3 - Error estimates indicating the numbers and percentages of GHCN stations for which the observed plant hardiness zone was lower, the same or higher than the estimated grid value.

\begin{tabular}{lccc}
\hline \# obs & \# lower (\%) & \# same (\%) & \# higher $(\%)$ \\
\hline 6512 & $1207(18.5)$ & $4324(66.4)$ & $981(15.1)$ \\
\hline
\end{tabular}

The plant hardiness zones used in this study were based on average annual extreme minimum temperature. In reality, plant survival is likely to be influenced by many factors including snow cover and winter rainfall (DeGaetano \& Shulman, 1990; Oullett \& Sherk, 1967; McKenney et al., 2001). Plant Hardiness zones are likely to be only a broad surrogate for potential plant distributions (McKenney et al., 2007). Likewise, the establishment of exotic pests will also be influenced by many factors other than plant hardiness. For example CLIMEX, a decision support system for pest risk analysis includes functions that account for growth and stress due to hot, cold, wet and dry (Sutherst et al., 1999). Likewise, the USDA APHIS NAPPFAST system uses infection, day degree and empirical models for risk mapping of exotic pests (Magarey et al., 2007). Prediction systems generally require either biological parameters or detailed distribution data. In contrast, hardiness zones provide a quick and easy method for an analyst to estimate and describe potential distribution. Many commodity pest risk assessments may analyze the climate potential for 20 or more pests including many that have limited or no biological/distribution data. For example, distribution data may be limited to simple literature reports at the scale of a country or less commonly for a secondary political unit. Biological data such as developmental requirements or cold tolerances required for deductive models are also not widely available for pests from developing countries (Nietshcke et al., 2007). Plant hardiness zone maps provide a simple alternative to intensive modeling efforts when detailed distributional and biological data are lacking. Future work may focus on developing hardiness maps incorporating degree days and available moisture.

The plant hardiness zone maps will be made available on the Internet at http://www.nappfast.org. The images will be available as geotiffs and can be imported into a geographic information system. 


\section{ACKNOWLEDGEMENTS}

We would like to thank Dr. Matthew Royer and the Cooperative Agricultural Pest Survey Program for project funding. We thank Dr. Robert Griffin of USDA APHIS CPHST PERAL for reviewing the manuscript. We also appreciate the helpful suggestions of two anonymous reviewers.

\section{REFERENCES}

CAPPIELLO, P.E.; LITTLEFIELD, L.E. Woody landscape plant cold-hardiness ratings. Orono: University of Maine/Maine Agricultural and Forest Experiment Station, 1994. 41p. (Technical Bulletin, 156).

CATHEY, H.M. USDA plant hardiness zone map. Washington, D.C.: USDA, 1990.(Web version of USDA. Miscellaneous Publication, 1475). 1990. Available at: http://www.usna.usda.gov/ Hardzone/. Acessed 23 July 2007.

DEGAETANO, A.T.; SHULMAN, M.D. A climatic classification of plant hardiness in the United States and Canada. Agricultural and Forest Meteorology, v.51, p.333-351, 1990.

EVANS, A.M.; TIMOTHY, A.E.; GREGOIRE, G. A geographically variable model of hemlock woolly adelgid spread. Biological Invasions, v.9, p.369-382, 2007.

FRANK, J.H.; McCOY, E.D. Introduction to insect behavioral ecology: the good, the bad, and the beautiful; non-indigenous species in Florida; invasive adventive insects and other organisms in Florida. Florida Entomologist, v.78, p.1-15, 1995.

GLEASON, B.E. Data documentation for data set 9101. Asheville: National Climatic Data Center, 2002. p.1-26.

JEFFERSON, L.; HAVENS, K.; AULT, J. Implementing invasive screening procedures: The Chicago Botanic Garden model. Weed Technology, v.18, p.1434-1440, 2004.

LORENC, A.C. A global three dimensional multivariate statistical interpolation scheme. Monthly Weather Review, v.101, p.701-721, 1981

MAGAREY, R.D.; BORCHERT, D.M.; FOWLER, G.L.; SUTTON, T.B.; COLUNGA-GARCIA, M.; SIMPSON, J.A. NAPPFAST: an internet system for the weather-based mapping of plant pathogens. Plant Disease, v.91, p.336-345, 2007.

McKENNEY, D.W.; HUTCHINSON, M.F.; PAPADOPOL, P.; CAMPBELL, K.; LAWRENCE, K. The generation of USDAequivalent extreme minimum temperature models and a comparison with Canada's plant hardiness zones. Canadian Journal of Plant Science, v.86, p.511-523, 2006
McKENNEY, D.W.; HUTCHINSON, M.F.; KESTEVEN, J.L.; VENIER, L.A. Canada's plant hardiness zones revisited using modern climate interpolation techniques. Canadian Journal of Plant Science, v.81, p.129-143, 2001.

McKENNEY, D.W.; PEDLAR, J.H.; LAWRENCE, K.; CAMPBELL, K.; HUTCHINSON, M.F.; Beyond traditional hardiness zones: using climate envelopes to map plant range limits. Bioscience, v.57, p.929-939, 2007.

NIETSHCKE, B.; MAGAREY, R.D.; BORCHERT, D.M.; CALVIN, D.D.; JONES, E.M. A developmental database to support insect phenology models. Crop Protection, v.26, p.1444-1448, 2007.

OULLET, C.E.; SHERK, L.C. Woody ornamental plant zonation. I. Indices of winter hardiness. Canadian Journal of Plant Science, v.47, p.231-238, 1967

PARMESAN, C.; YOHE, G. A globally coherent fingerprint of climate change impacts across natural systems. Nature, v.421, p.37-42, 2003.

PETERSON, T.C.; VOSE, R.S. An overview of the Global Historical Climatology Network temperature data base. Bulletin of American Meteorological Society, v.78, p.2837-2849, 1997.

PLANT hardiness zone map, backyard gardener. Available at: http:/ /www.backyardgardener.com. Accessed 23 Aug. 2007.

SUTHERST, R.W.; MAYWALD, G.F.; YONOW, T.; STEVENS, P.M. CLIMEX: predicting the effects of climate on plants and animals; user guide. Melbourne: CSIRO, 1999. 88p.

UNITED STATES DEPARTMENT OF AGRICULTURE - USDA. Guidelines for pathway-initiated pest risk assessments: version 5.1. Riverdale: USDA/APHIS, 2003. $41 \mathrm{p}$.

VENETTE, R.C; GOULD, J.R. A pest risk assessment for Copitarsia spp.: insects associated with importation of commodities into the United States. Euphytica, v.148, p.165-183, 2006.

WALTHER, G.R.; POST, E.; CONVEY, P.; MENZEL, A.; PARMESAN, C.; BEEBEE, T.J.C.; FROMENTIN, J.; HOEGHGULDBERG, O.; BAIRLEIN, F. Ecological responses to recent climate change. Nature, v.416, p.389-395, 2002.

WILKS, D.S. Statistical methods in the atmospheric sciences. San Diego: Academic Press, 1995. 467 p.

WOODWARD, F.I.; WILLIAMS, B.G. Climate and plant distribution at global and local scales. Vegetatio, v.69, p.189-197, 1987.

Received November 01, 2007

Accepted August 18, 2008 